52, Pseudococcus sp. (Fullaway).

Orthoptera.

53, Periplaneta americana (L.). (Fullaway).

54, Polyzosteria soror Brunn. (Fullaway).

55, Phyllodromia sp. (Fullaway).

Euplexoptera.

56, Anisolabis annulipes (Luc.). (Fullaway).

57, Anisolabis maritima (Bon.)? (Fullaway).

Thysanoptera.

58, Thrips. Undetermined. (Fullaway).

Psocoptera.

59, Ectopsocus fullawayi Enderlein. (Fullaway).

60, Kilaueaella sp. (Fullaway).

\title{
Two New Species of Trichogrammidae.
}

BY D. T. FULLAWAY.

\section{Jassidophthora lutea n. sp.}

Lemon yellow, microscopically reticulate and roughened, almost opaque. Head large, transverse, more or less subquadrate; eyes round, front and cheeks broad, ocelli arranged in an equilateral triangle near the vertex; lateral members not close to margin of eye. Antennae 9-jointed, inserted on middle of face, scape rather slender, longer than the club, pedicel a trifle shorter and more or less obconic, all the funicle joints transverse, the 2nd the largest, club stout and distinctly three-jointed, all the joints outwardly from the scape bearing some stout setae. Pronotum narrow, mesonotum with distinct parapsides, scutellum transverse with a few short, bristly hairs. Abdomen ovate, the lateral margins marked with fuscous. Ovipositor only slightly exserted. Wings twice as long as wide, margiual vein though fairly long not reaching beyond the middle, also greatly thickened and somewhat eurved basally away from the costal margin, stigmal vein short and broad, at right angles to the marginal with a short spur on outer face and contained

Proc. Haw. Ent. Soc., III, No. 1, September, 1914. 
in a fuscous cloud which reaches half way across the wing bending backwards in the form of an arch. A few bristles on costal margin proximally, the marginal fringe short but somewhat lengthened outwardly and about as long as a fifth of the greatest width of the wing on the posterior margin. Discal ciliation rather closely set, the linear arrangement more or less indistinct. Hind wings long and slender with two rows of discal cilia and a short costal and much longer anal fringe.

Length about $1 \mathrm{~mm}$.

\section{Westwoodella caerulocephala n. sp.}

Lemon yellow, head with a bluish tinge, legs pallid. Microscopically reticulate, moderately shining. Head subquadrate, the face almost vertical, slightly concave, front wide between the eyes, the inner margins of which are almost straight. Ocelli just below the vertex in a small equilateral triangle, occiput curving gently on to the rather broad cheeks. Antennae 7 -jointed, with a distinct ring joint, inserted on the middle of the face; scape long and slender, pedicel shorter and stouter, the single funicle joint as broad as the pedicel and club, about as long as the 1st joint of the latter and more or less obconic; club slightly swollen, nearly as long as the scape and acutely pointed at apex. Pronotum narrow, mesonotum broadly transverse, moderately convex, parapsidal furrows indistinct, scutellum small, convex. Abdomen short oval, the apex conically produced. Wings slender, with long marginal fringe and indistinctly hairy, 5 or 6 lines on the disc outwardly. Marginal vein a trifle shorter than submarginal but reaching middle of wing. There are three large setae and several smaller ones on its outer face. Stigmal vein short and capitate with an acute projection on its apical side and continued in a fuscous cloud almost to middle of wing.

Length .8 mm., expanse of wings $1.35 \mathrm{~mm}$; greatest width of forewing .18 mm.

This and the preceding species were bred from eggs of a Jassid (Draeculacephala mollipes) occurring in the swamps at Kewalo, Honolulu. Specimens were submitted to Dr. Perkins for determination, who pronounced them new species in their respective genera and turned them over to the writer for description. 


\section{$2 \mathrm{BHL}$ Biodiversity Heritage Library}

Fullaway, David T. 1914. "Two new species of Trichogrammatidae." Proceedings of the Hawaiian Entomological Society 3, 22-23. https://doi.org/10.5962/bhl.part.24592.

View This Item Online: https://www.biodiversitylibrary.org/item/41056

DOI: https://doi.org/10.5962/bhl.part.24592

Permalink: https://www.biodiversitylibrary.org/partpdf/24592

\section{Holding Institution}

Smithsonian Libraries

\section{Sponsored by}

Smithsonian

\section{Copyright \& Reuse}

Copyright Status: NOT_IN_COPYRIGHT

This document was created from content at the Biodiversity Heritage Library, the world's largest open access digital library for biodiversity literature and archives. Visit BHL at https://www.biodiversitylibrary.org. 